\title{
Isolation of Acrylamide-Resistant Facultative \\ Anaerobes from Methane-Fermented Swine \\ Waste-Water and Biodegradation of \\ Acrylamide by Immobilized Cells \\ of Isolated Bacterial Strain
}

\author{
Shin-ichi Kamata, Norihide Kaknchi, Akihiko Motozawa, \\ Hiroharu OTSUKA and Kazuo UCHIDA \\ Department of Veterinary Hygiene, Nippon Veterinary \\ and Animal Science University, Musashino-shi 180
}

(Received March 27, 1992)

\begin{abstract}
The effect of acrylamide (ACR) on methane fermentation was examined. The volume of gas production was found extremely decreased in the presence of more than $3.3 \mathrm{mg} / \mathrm{l}$ of $\mathrm{ACR}$. When isolation of ACR-resistant facultative anaerobes from the digested sludge was attempted, E. coli SK-1 strain against which ACR had minimum inhibitory concentration (MIC) of $20,000 \mathrm{mg} / l$ was isolated. This bacterial strain was found to utilize $\mathrm{ACR}$ as a carbon source. On examining the degradation of $\mathrm{ACR}$ by this bacterial strain immobilized by the PVA-boric acid method, $52 \%$ was decomposed in four days. These results showed that methane fermentation was affected in the presence of a very small amount of ACR and also suggested that $E$. coli SK-1 isolated from the digested sludge acclimated by addition of ACR can be utilized as an immobilized bioreactor.
\end{abstract}

Anim. Sci. Technol. (Jpn.) 63 (12) : 1228-1233, 1992 Key words : acrylamide, methane fermentation, biodegradation, Escherichia coli, bacterial immobilization

Acrilamide (ACR, $\mathrm{CH}_{2}=\mathrm{CHCONH}_{2}$ ) is used as a powerful paper strengthener, a flocculant in the treatment of water, a soil stabilizer and so on. In the field of biochemistry, it is utilized in electrophoresis ${ }^{2)}$. ACR-polymer of low toxicity is used for the three purposes mentioned above ${ }^{8,10}$. Since commercial polyACR contains $0.3-5.0 \%$ hypertoxic ACRmonomer, scrupulous care is demanded in the use of poly-ACR ${ }^{5,3,10)}$. In fact, CROLl et al. ${ }^{47}$ have measured the concentration of ACR in industrial waste-water from factories which used poly-ACR and detected $0.47-42 \mu \mathrm{g} / l$ of hypertoxic ACR-monomer. It is presumed that either ACR-monomer was originally contained in commercial poly-ACR or polymer was decomposed into monomer.

The toxicity of ACR-monomer in animals causes injuries mainly to the central and peripheral nervous systems ${ }^{6}$. $\mathrm{LD}_{50}$ of $\mathrm{ACR}$ monomer in rats, guinear pigs and rabbits has been estimated to range from 100 to $200 \mathrm{mg} /$ $\mathrm{kg}^{7,10)}$. The biodegradation of ACR has been described under an aerobic condition ${ }^{1,3,4,11}$. However, the influence of ACR on methane fermentation and the biodegradation of ACR 


\section{Biodegradation of Acrylamide by $E$. coli Isolated from Methane Fermentation}

by facultative anaerobes have not been studied. This study was designed to examine the influence of $A C R$ on methane fermentation of pretreated swine feces. Isolation of ACRresistant facultative anaerobes from the digested sludge was also attempted. In addition, the biodegradation of $\mathrm{ACR}$ was investigated using an ACR-resistant strain isolated and immobilized by the polyvinyl alcohol (PVA)boric acid method ${ }^{5)}$.

\section{Materials and Methods}

\section{Evaluation of the effect of $A C R$ on} methane fermentation

Methane fermentation was carried out under the operating condition shown in Table 1. Swine feces was used as a waste water sample. It was diluted three times and filtered through a 32-mesh filter. It was adjusted to the concentration of biochemical oxygen demand $12,000 \mathrm{mg} / l$. Digested sludge was grown and acclimated at our Laboratory.

Two 1,000-m $l$ flasks (effective capacity : $600 \mathrm{ml}$ each) were used as fermenters. One was used without $\mathrm{ACR}$ as a control, and the other with $0.5-3.0 \mathrm{mg}$ of ACR (Run). During the first one week, $0.5 \mathrm{mg}$ of ACR was added daily and subsequently, the daily amount was increased by $0.5 \mathrm{mg}$ at weekly intervals.

Table 1. Operating condition of methane fermentation

\begin{tabular}{lcc}
\hline \hline & Control & Run \\
\hline BOD volume loading, g/l/d & 20 & 20 \\
Influent BOD, mg/l & 12,000 & 12,000 \\
Fermentation tank capacity, $\mathrm{m} l$ & 600 & 600 \\
Influent volume, ml & 30 & 30 \\
Detention time, day & 20 & 20 \\
Initial sludge volume, \% & 20 & 20 \\
Acrylamide, mg/l & 0 & $0.5-3.0^{*}$ \\
Temperature, ${ }^{\circ} \mathrm{C}$ & $35 \pm 1$ & $35 \pm 1$ \\
\hline
\end{tabular}

*Acrylamide was added to Run in daily amount of $0.5 \mathrm{mg}$ during the first one week. The daily amount was increased by $0.5 \mathrm{mg}$ at weekly intervals.
Methane fermentation was continued for six weeks.

ACR used was a $98 \%$-purity product for electrophoresis (Nacalai Tesque, Inc., Japan). The concentration of methane was determined using a Model 373 Thermal-Conductivity Gas Chromatograph (Gasukuro Kogyo Inc., Japan).

2. Isolation of ACR-resistant facultative anaerobes

Isolation of ACR-resistant bacteria was carried out by the following method. The tripticase soy agar medium (TS agar, BBL) containing $2,000 \mathrm{mg} / l$ of ACR was inoculated with sludge obtained after 35 weeks of fermentation in the Run. It was subjected to aerobic culture for 24 hours at $37^{\circ} \mathrm{C}$. The bacterial colony formed on the agar was again inoculated to TS agar and subjected to anaerobic culture for 24 hours at $37^{\circ} \mathrm{C}$ using a Gas Pac anaerobic system (BBL). The bacterial strains isolated were stored on TS agar slants.

3. Measurement of the minimum inhibitory concentration (MIC) of ACR against ACR-resistant strains

The bacterial strains isolated were inoculated to a TS broth containing $2.5,5.0,7.5,10,15$ or $20 \mathrm{~g} / l$ of $\mathrm{ACR}$ and subjected to aerobic culture for 24 hours at $37^{\circ} \mathrm{C}$. They were then inoculated to TS agar and incubated under the same condition. The proliferation of bacterial cells was then examined.

\section{Biodegradation of $A C R$}

The biodegradation of ACR was tested using free and immobilized cells of the bacterial strain which was found having the highest resistance to ACR. Cells were mass-cultured with shaking in $1,000 \mathrm{~m} l$ of TS broth at $37^{\circ} \mathrm{C}$ for 24 hours. They were then condensed by centrifugation (centrifuge: Kokusan $\mathrm{H}-103$ RLH) at $5,000 \mathrm{rpm}$ for five minutes at $4^{\circ} \mathrm{C}$. The condensate was washed twice in phosphate buffer. Free cells for the testing of ACR biodegradation were prepared by inoculating the bacteria to $10 \mathrm{ml}$ each of Broth $\mathrm{A}$ and $\mathrm{B}$. The biodegradation of $\mathrm{ACR}$ by the free cells 
was examined at $30^{\circ} \mathrm{C}$ for three days. Broth $\mathrm{A}$ was composed of $0.2 \mathrm{~g}$ of $\mathrm{KH}_{2} \mathrm{PO}_{4}, 1.15 \mathrm{~g}$ of $\mathrm{Na}_{2} \mathrm{HPO}_{4}, 0.1 \mathrm{~g}$ of ACR and $1,000 \mathrm{~m} l$ of water. Broth $\mathrm{B}$ contained $0.5 \mathrm{~g}$ of L-asparagine additionally.

Immobilized cells were prepared by the polyvinyl alcohol (PVA)-boric acid method of KAKIICHI et al. ${ }^{5)}$ Immobilized cells were aggregated into 360 beads (mean diameter $3 \mathrm{~mm}$ ) and were placed into four test tubes to contain $200,100,50$ and 10 beads respectively. Then $10 \mathrm{ml}$ of broth A were added to the tubes and shaken. The biodegradation of ACR was examined at $30^{\circ} \mathrm{C}$ for four days.

The concentration of $\mathrm{ACR}$ was determined using a Shimadzu LC-6 A High Performance Liquid Chromatograph (HPLC) equipped with a Shim-Pack CLC-ODS column and a UV detector set at $210 \mathrm{~nm}$.

\section{Results}

\section{Effect of ACR on methane fermentation}

Table 2 and Fig. 1 show the changes in the biogas production and the concentration of methane in it, respectively. The gas production in the control ranged from 158 to 175 $\mathrm{m} l /$ day. In the Run, almost the same volume of gas was produced as in the control until the third week until when the daily addition of ACR was increased from 0.5 to $1.5 \mathrm{mg}$. The gas production was significantly decreased,

Table 2. Comparison of biogas production

\begin{tabular}{llc}
\hline \multirow{2}{*}{ Week } & \multicolumn{2}{c}{ Gas production*, ml/day } \\
\cline { 2 - 3 } & Control & Run** \\
\hline 1st & $163 \pm 13$ & $158 \pm 16 \quad(0.5)$ \\
2nd & $172 \pm 16$ & $169 \pm 20(1.0)$ \\
3rd & $158 \pm 11$ & $162 \pm 8(1.5)$ \\
4th & $167 \pm 24$ & $98 \pm 22^{\text {a) }}(2.0)$ \\
5th & $175 \pm 22$ & $47 \pm 8^{\text {a) }}(2.5)$ \\
6th & $159 \pm 26$ & $16 \pm 13^{\text {a) }}(3.0)$ \\
\hline
\end{tabular}

* Mean $\pm \mathrm{SD}$.

** In parentheses are shown the amount (mg) $30 \mathrm{~m} / /$ day) of acrylamide added.

a) $\mathrm{P}<0.01$ as compared with control. compared to the control, from the fourth week from when the amount of ACR added was increased to $2.0 \mathrm{mg} /$ day or more.

The concentration of methane in the gas produced ranged from 59 to $66 \%$ in the control and from 57 to $69 \%$ in the Run, thus showing no significant difference.

2. ACR-resistant strains and MIC of ACR

As shown in Table 3 , five facultative anaerobic strains were isolated ; E. coli SK-1, E. coli SK-2, Serratia sp., Proteus sp. and Micrococus sp. MICs of ACR against these strains were $20,000,15,000,7,500,5,000$ and $2,500 \mu \mathrm{g} / \mathrm{ml}$ respectively. Thus, $E$. coli $\mathrm{SK}-1$ was found to have the highest resistance to ACR.

3. Biodegradation of ACR by E. coli SK-1

Fig. 2 shows the biodegradation of ACR by the free cells of $E$. coli SK-1 in the presence

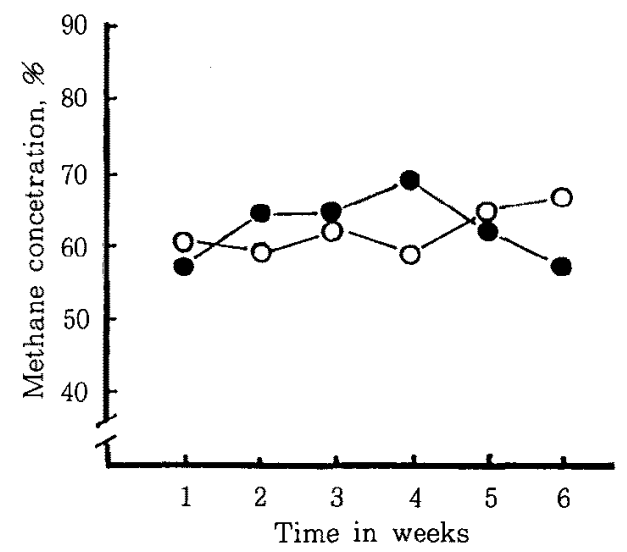

Fig. 1. Changes of methane concetration in biogas produced.

$O$ : Control : Run

Table 3. MIC of $\mathrm{ACR}$ against ACR-resistant bacterial strains

\begin{tabular}{lc}
\hline \hline Strain & MIC, $\mu \mathrm{g} / \mathrm{m} l$ \\
\hline Escherichia coli $\mathrm{SK}-1$ & 20,000 \\
Escherichia coli $\mathrm{SK}-2$ & 15,000 \\
Serratia sp. & 7,500 \\
Proteus sp. & 5,000 \\
Micrococcus sp. & 2,500 \\
\hline
\end{tabular}


Biodegradation of Acrylamide by $E$. coli Isolated from Methane Fermentation

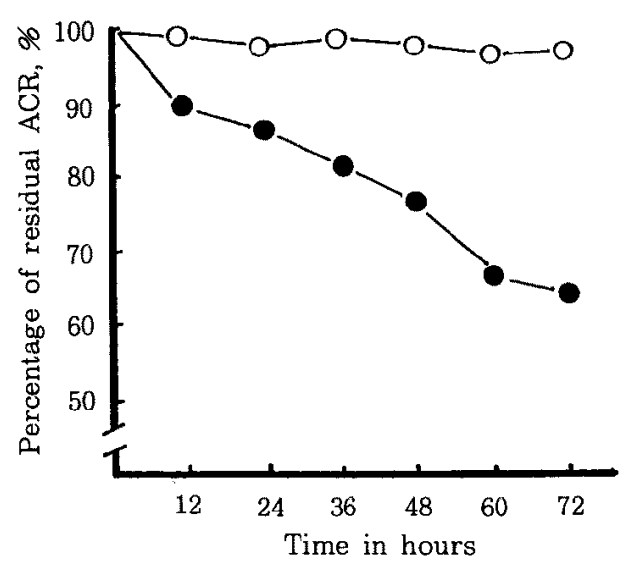

Fig. 2. Effect of L-asparagine as carbon source on ACR degradability by free $E$. coli SK-1 cells.

$O:$ In the broth containing $100 \mathrm{mg} / l$ of ACR and $500 \mathrm{mg} / \mathrm{l}$ of L-asparagine

- : In the broth containing $100 \mathrm{mg} / l$ of $\mathrm{ACR}$ only

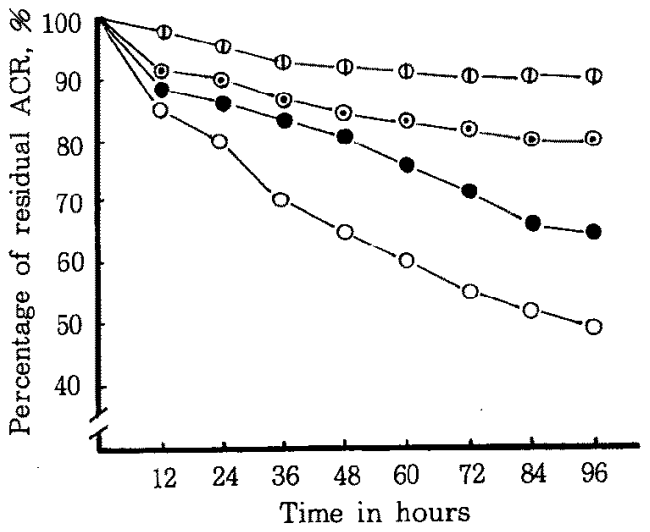

Fig. 3. ACR degradability in relation to the number of beads of immobilized $E$. coli SK-1 cells.
$O: 200$ beads
: 100 beads
$\odot$ : 50 beads
(1): 10 beads

and absence of L-asparagine.

Biodegradation of $\mathrm{ACR}$ was not recognized in the broth contaning $100 \mathrm{mg} / l$ of $\mathrm{ACR}$ and $500 \mathrm{mg} / l$ of $\mathrm{L}$-asparagine. On the other hand, $35 \%$ of ACR was degraded in 72 hours in the broth containing $100 \mathrm{mg} / l$ of ACR only.
4. Biodegradation of ACR by immobilized cells of $E$. coli $S K-1$

Fig. 3 shows the relation between the degradation of ACR and the number of beads of E. coli SK-1 cells immobilized by the PVA-boric acid method.

The rate of ACR degradation increased with increase in the number of beads. It was found that $10,20,36$ and $52 \%$ of ACR were degraded in four days in the presence of 10,50, 100 and 200 beads immobilized E. coli SK-1 cells, respectively.

\section{Discussion}

The effect of ACR on methane fermentation was investigated in this experiment. Since the biogas production was considerably decreased by daily addition of $2.0 \mathrm{mg} / 30 \mathrm{ml}$ of ACR to the fermentation tank of the effective capacity of $600 \mathrm{ml}$, it was presumed that the fermentation was disturbed when the concentration of ACR in the fermenter exceeded $3.3 \mathrm{mg} / \mathrm{l}$. MoRIMOTo et $a l .{ }^{93}$, who detected $220-1,200 \mathrm{mg} / l$ of ACR in well water in Fukuoka Prefecture in 1974, have attributed this finding to the melting-out from the road paved with an acrylamide soil stabilizer. If such $\mathrm{ACR}$-contaminated well water is used for cleaning of animal sheds or as drinking water for domestic animals, it is presumed that methane fermentation is disturbed and animals suffer from poisoning.

The biodegradation of $\mathrm{ACR}$ in natural enviroments has been described ${ }^{3,4,11)}$. Croll et $a l .{ }^{4)}$ have found that when river water containing and not contaning acclimated microorganisms were treated with $8 \mu \mathrm{g} / l$ of $\mathrm{ACR}$ and were slightly aerated, the degradation of $\mathrm{ACR}$ required more than 100 hours in the river water not containing microorganisms, while ACR was completely degraded in 40 hours in the river water containing microorganisms. Arimitsu et al. ${ }^{1)}$ have described that when water influent into a water purification plant was treated with $20 \mu \mathrm{g} / l$ of ACR and was then 
aerated, the concentration of ACR was decreased to $0.5 \mu \mathrm{g} / l$ in five days. In a degradation experiment of $200 \mathrm{mg} / l$ of ACR using ACR-decomposing bacteria (Pseudomonas sp.) isolated from soil, SHANKER ${ }^{11}$ has found complete degradation of ACR in six days. These studies have estimated the biodegradability of ACR by microbial flora in aerated water with high concentration of dissolved oxygen or by aerobic bacteria. The biodegradation of $\mathrm{ACR}$ by facultative anaerobic bacteria has not been studied. In this experiment, we sought ACRresistant facultative anaerobes in the ACRadded digested sludge and isolated $E$. coli SK-1 against which ACR was found to have MIC of $20,000 \mathrm{mg} / l$. The degradation experiment was carried out on suspicion that this might be not only an ACR-resistant strain but also a degrader of ACR. It was found that $E$. coli SK-1 did not decompose ACR in the broth containing both ACR and L-asparagine but did in the broth containing ACR alone. This fact suggests that although this bacterial strain utilizes L-asparagine as a carbon source in preference to ACR, obviously it also utilizes ACR as a carbon source. It is at the same time presumed that the biodegradation of ACR by this bacterial strain is hindered when there is another carbon source more preferred by the bacteria to utilize. When the relation between the number of cell beads and biodegradation of ACR was examined using the $E$. coli SK-1 cells immobilized by the PVA-boric acid method, the biodegradation progressed at the highest rate in the presence of 200 beads and the rate of biodegradation tended to decrease with decrease in the number of beads.

From the above results, the inhibitory concentration of ACR against methane fermentation was estimated to be approximately 3.3 $\mathrm{mg} / l$. It was demonstrated that $E$. coli $\mathrm{SK}-1$ which is an ACR-resistant faculative strain utilized $\mathrm{ACR}$ as a carbon source. It was also suggested that this bacterial strain can be used as a bioreactor for biodegradation of ACR by immobilization of its cells by the PVA-boric acid method. We intend to attempt a longterm, comprehensive study on biodegradation of ACR.

\section{References}

1) Arimitsu, H., H. Ikebukuro and I. Sero, The biological degradability of acrylamide monomer. Jpn. J. Wat. Work. Assoc., 487: 31-39. 1979,

2) Asano, S., Production of acrylamide and its utilization, Gendaikagaku, May : 40-47. 1984.

3) Croll, B.T., A.J. Gabaccia and H.W. Senn, The assimilation behavior of certain toxic organic compounds in natural water. Sew. Ind. Wast., 28 : 1137-1146. 1956.

4) Croll, B.T., G.M. Arkell and R.J. HODGE, Residues of acrylamide in water. Wat. Res., 8: 989-993. 1974.

5) Kakitchi, N., S. ShibuYa, K. Akita, Y. Sugimoto, T. Oshida, M. Hayashi, S. Kamata, K. Komine, H. Otsuka and K. UCHIDA, Immobilization of denitrifying bacteria using polyvinyl alcohol and denitrification by immobilized cells. Anim. Sci. Technol. (Jpn.), 63: 47-53. 1992.

6) Kuperman, A., Effects of acrylamide on the cetral nervous system of the cat. J. Pharmacol. Exp. Therap., 123 : 180-192. 1958.

7) MCcollister, D.D., Toxicology of acrylamide. Toxicol. Appl. Pharmacol., 6 : 172-184. 1964.

8) MCcollister, D.D., Toxicology investigation of polyacrylamida. Toxicol. Appl. Pharmacol., $7:$ 639-651. 1965.

9) Morimoto, M., A. Mori, S, Nakamura, K. Fukamachi, S. Takao, K. Morita, Y. Nagabuchi, H. MoRIKI, Y. Ezaki, A. Kishikawa, S. Tagami, Y. KifuJi, K. Takahashi, N. Saruta and K. Matsuo, The occurrence of poisoning case through well-water contaminated by acrylamide in Shingu-machi, Fukuoka Prefecture. J. Wat. Wast., 17 : 1307-1318. 1975.

10) OKAZAWA, K., Toxicity of acrylamide and safety of polyelectrolite. J. Wat. Wast., 18 : 15-21. 1976.

11) SHANKER, R., Microbial degradation of acrylamide monomer. Arch. Mlicrobiol., 154 : 192-198. 1990. 
Biodegradation of Acrylamide by E. coli Isolated from Methane Fermentation

\title{
豚舎污水処理メタン発酵からのアクリルアミド而性 通性嫌気性菌の分離と固定化菌体による \\ アクリルアミドの分解性
}

\author{
鎌田信一・柿市徳英・本澤明彦・大塚宏治・内田和夫 \\ 日本獣医畜産大学, 武蔵野市 180
}

\begin{abstract}
アクリルアミド〈ACR）のメタン発醭に対する影響試験を試みたところ, $\mathrm{ACR} 3.3 \mathrm{mg} / \mathrm{l}$ 以上で発 生ガス量が極度に低下した。このメタン発酥スラッジから ACR 而性通性矰気性菌の分離を試みた結 果, ACR に対する最小発育阻止港度 (MIC) が $20,000 \mathrm{mg} / l$ のE. coli SK-1 株が分離された，ま た，本菌株は ACR を炭素源として利用することが明らかにされた，さらに，本菌株をPVA-硼酸法 により固定化し，ACR の分解を調べたところ，4 日間で $52 \%$ が分解された．以上より，メタン発醉 は微量の ACR の存在で阻害されることが明らかとされた。また，ACRに上り馴化したメタン発酵 スラッジ由来の E. coli SK-1 は固定化したバイオリアクターとしての応用の可能性が示唆された.
\end{abstract}

日畜会報、63 (12)：1228-1233，1992 